$$
\begin{array}{r}
\text { Pontifícia Universidade Católica } \\
\text { do Rio de Janeiro }
\end{array}
$$

Nély Silva da Motta Mesquita

\title{
Legibilidade textual nos Cadernos Didáticos de EJA: questões de processamento da leitura
}

\section{Dissertação de Mestrado}

Dissertação de Mestrado apresentada como requisito parcial para obtenção do grau de Mestre em Letras do Departamento de Letras da PUC-Rio como parte dos requisitos parciais para obtenção do título de Mestre em Letras.

Orientadora: Profa. Erica dos Santos Rodrigues

Co-orientadora: Profa. Violeta de San Tiago Dantas Barbosa Quental

Rio de Janeiro

Abril de 2011 


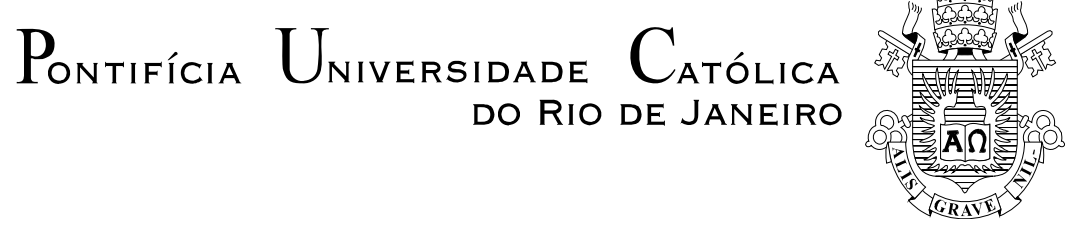

Nély Silva da Motta Mesquita

\title{
Legibilidade textual nos Cadernos Didáticos de EJA: questões de processamento da leitura
}

\begin{abstract}
Dissertação apresentada como requisito parcial para obtenção do grau de Mestre pelo programa de Pós-Graduação em Letras do Departamento de Letras do Centro de Teologia e Ciências Humanas da PUC-Rio. Aprovada pela Comissão Examinadora abaixo assinada.
\end{abstract}

\author{
Profa. Erica dos Santos Rodrigues \\ Orientadora \\ Departamento de Letras - PUC-Rio
}

Profa. Violeta de San Tiago Dantas Barbosa Quental

Co-Orientadora

Departamento de Letras - PUC-Rio

Profa. Beatriz de Castro Barreto Departamento de Letras - PUC-Rio

Profa. Tânia Mara Gastão Saliés

UERJ

Profa. Denise Berruezo Portinari Coordenadora Setorial do Centro de Teologia e Ciências Humanas - PUC-Rio

Rio de Janeiro, 07 de abril de 2011. 
Todos os direitos reservados. É proibida a reprodução total ou parcial do trabalho sem autorização da universidade, da autora e da orientadora.

\section{Nély Silva da Motta Mesquita}

Graduou-se em Letras - Universidade Federal do Rio de Janeiro; atua na linha de pesquisa "A leitura e a produção escrita numa abordagem psicolinguística: demandas cognitivas e especificidades de processamento”.

Ficha Catalográfica

Mesquita, Nély Silva da Motta

Legibilidade textual nos Cadernos Didáticos de EJA: questões de processamento da leitura / Nély Silva da Motta Mesquita; orientadora: Erica dos Santos Rodrigues; coorientadora: Violeta de San Tiago Dantas Barbosa Quental. 2011.

97 f. ; $30 \mathrm{~cm}$

Dissertação (mestrado) - Pontifícia Universidade Católica do Rio de Janeiro, Departamento de Letras, 2011. Inclui bibliografia

1. Letras - Teses. 2. Leitura. 3. Métricas de legibilidade. 4. Educação de jovens e adultos. 5. Gêneros textuais. I. Rodrigues, Erica dos Santos. II. Quental, Violeta de San Tiago Dantas Barbosa. III. Pontifícia Universidade Católica do Rio de Janeiro. Departamento de Letras. IV. Título. 


\section{Agradecimentos}

À minha família, pelo apoio e incentivo.

À minha orientadora, Erica Rodrigues, pelo apoio profissional e exemplo.

À minha co-orientadora, Violeta Quental, pelo apoio profissional e exemplo.

A todos os professores do mestrado, por me capacitarem.

Aos meus colegas de pós, com quem troquei experiências valiosas.

Aos professores que participaram da Comissão Examinadora.

A PUC-Rio, pelos auxílios concedidos, sem os quais este trabalho não poderia ter sido realizado. 


\section{Resumo}

Mesquita, Nély Silva da Motta; Rodrigues, Erica dos Santos (Orientadora); Quental, Violeta de San Tiago Dantas Barbosa (Co-orientadora). Legibilidade textual nos Cadernos Didáticos de EJA: questões de processamento da leitura. Rio de Janeiro, 2011. 97p. Dissertação de Mestrado - Departamento de Letras, Pontifícia Universidade Católica do Rio de Janeiro.

Este trabalho visa investigar o processamento da leitura, fazendo uma reflexão sobre a compreensão e a construção de sentidos para o texto. São abordadas as novas vertentes teóricas sobre o processamento da leitura com foco nas habilidades do leitor e nas dificuldades apresentadas no próprio texto, inclusive em textos multimodais. Os resultados dos testes mais conhecidos na avaliação de leitura, o PISA e o ENCCEJA, também são comentados, observandose que o Brasil precisa melhorar seu desempenho em leitura. Ainda fazemos uma incursão no conceito de gênero e na ação facilitadora de compreensão que resulta do conhecimento sobre gêneros textuais. Por acreditarmos na importância de entender melhor a questão do analfabetismo funcional e as políticas públicas de enfrentamento desse problema, escolhemos trabalhar com o material didático destinado à Educação de Jovens e Adultos (EJA), a Coleção Cadernos Didáticos de EJA. A análise dos gêneros textuais e dos índices de legibilidade dos textos da Coleção Cadernos Didáticos de EJA é apresentada após a explicação da metodologia adotada. Além da análise dos gêneros e dos recursos multimodais presentes nos textos, foi elaborada uma tabela de métricas selecionadas da ferramenta Coh-Metrix-Port com os resultados obtidos pela submissão dos textos dos Cadernos Didáticos à ferramenta. Esses resultados permitem avaliar a dificuldade de leitura desses textos pela comparação das métricas de legibilidade, tanto as obtidas com a ferramenta como aquelas resultantes da caracterização dos gêneros. A pesquisa sinalizou para a relevância da utilização desses índices na avaliação da complexidade dos textos a serem empregados no ensino, permitindo que se estabeleça uma ordenação, em termos de grau de legibilidade, dos textos a serem trabalhados pelo professor.

\section{Palavras-chave} Textuais.

Leitura; Métricas de Legibilidade; Educação de Jovens e Adultos; Gêneros 


\section{Abstract}

Mesquita, Nély Silva da Motta; Rodrigues, Érica dos Santos (Advisor); Quental, Violeta de San Tiago Dantas Barbosa (Co-advisor). Textual readability in brazilian workbooks for adult education (EJA): reading processing issues. Rio de Janeiro, 2011. 97p. MSc Dissertation Departamento de Letras, Pontifícia Universidade Católica do Rio de Janeiro.

This research aims to investigate the processing of reading, making some considerations about the comprehension and the construction of senses to the text. The new theoretical approaches about the processing of reading are presented focusing on readers' abilities and difficulties presented by texts themselves, including multimodal ones. The results of the most well-known tests on reading evaluation, PISA and ENCCEJA, are also commented, observing that Brazil needs to improve its performance in reading. We also discuss the concept of genre and we point to the facilitated comprehension that results from the knowledge about textual genres. As we believe in the importance of a better understanding of the question of functional illiteracy and how the public policy is facing this problem, we have chosen to work with some didactic material indicated to the education of youths and adults who are out of regular courses, the Didactic Collection of Textbooks for Youths and Adults, EJA Textbooks. The analysis of textual genres and readability rates in the texts of this Didactic Collection is presented after the explanation of the adopted methodology. There is also an examination of the multimodal resources appearing in the texts, and a table of the selected metrics of Coh-Metrix-Port with the results obtained with the submission of the texts of EJA Textbooks to this tool. These results allow the evaluation of reading difficulties presented by these texts, comparing the readability metrics, not only the ones obtained with the tool but also the ones resulting from the characterization of the genres. This research points to the relevance of using these results in the evaluation of the complexity of texts to be used in teaching, allowing establishing an ordination, in terms of the grade of readability in texts to be used by teachers.

\section{Keywords}

Reading; Readability Metrics; Adult Education; Text Genres. 


\section{Sumário}

$\begin{array}{ll}\text { 1. Introdução } & 9\end{array}$

2. Leitura e Compreensão 12

2.1. O que é ler e o que é compreender 12

2.2. O conceito de legibilidade textual 14

2.3. Modelos de leitura $\quad 17$

2.4. O conceito de letramento 21

2.5. O teste Pisa e o ENCCEJA 25

3. O livro didático e a abordagem com gêneros 29

3.1.1. O conceito de gênero $\quad 29$

3.1.2. O LD como suporte de gêneros 34

3.2. A multimodalidade como forma de maximizar o sentido 36

4. A Educação de Jovens e Adultos (EJA) 39

5. Metodologia 42

5.1. O corpus $\quad 42$

5.2. Procedimentos de análise $\quad 44$

5.2.1. Coh-Metrix-Port - procedimentos de submissão dos textos e parâmetros de legibilidade

5.2.1.1. Procedimentos de submissão 46

5.2.1.2. Métricas do Coh-Metrix-Port 48

5.2.1.3. Métricas selecionadas para análise da legibilidade dos CDs 52

6. Resultados $\quad 59$

6.1. Gêneros textuais $\quad 59$

6.2. Gêneros verbo-visuais $\quad 62$

6.3. Atividades propostas nos Cadernos do Professor 68

6.4. Ordenação dos Cadernos Didáticos em termos de grau de legibilidade a partir dos parâmetros selecionados do Coh-Metrix-Port 73

6.5. Análise comparativa entre os resultados do Coh-Metrix e os gêneros textuais mais recorrentes nos CDS 81

7. Considerações finais 83

8. Referências bibliográficas 86

9. Anexos 89

Anexo 1 - Tabela geral de gêneros, multimodalidade e atividades 89

Anexo 2 - Tabela de índices de legibilidade $\quad 95$ 


\section{Lista de figuras e tabelas}

Figura 1: Quadro geral das categorias analíticas relativas ao conceito de gêneros textuais (Marcuschi, 2008)

Figura 2: Página inicial do Coh-Metrix-Port.

Figura 3: Página de cadastramento do Coh-Metrix-Port. 47

Figura 4: Página que registra o cadastramento 47

Figura 5: Página onde o usuário cola o texto a ser submetido 48

Tabela 1 - Frequência de gêneros 60

Tabela 2 - Frequência de gêneros verbo-visuais 64

Tabela 3 - Frequência de atividades com gêneros $\quad 69$

Tabela 4 - Resultados dos índices do Coh-Metrix selecionados para fins de comparação dos CDs quanto à legibilidade $\quad 74$

Tabela 5 - Hierarquia de legibilidade dos CDs 76

Tabela 6 - Resultados dos parâmetros de legibilidade/conectivos $\quad 79$

Tabela 7 - Comparação dos CDs, em termos de ranking de legibilidade, com base no Índice Flesch e no conjunto de parâmetros selecionados 